Historical Notes

\title{
Medical Genetics in Classical Ayurvedic Texts: A Critical Review
}

\author{
P Ram Manohar
}

(Received 18 May 2016)

\begin{abstract}
In the early classical texts of Ayurveda, there are descriptions regarding the genetic basis of diseases. The Caraka Samhitā explains that the human body in its entirety is represented in a seed form in the male and female reproductive elements. The complete blue print is called a $b \vec{j} j a$, which is composed of many components called the bijjabhägas. The bijjabhāgas are further made up of smaller parts called as the büjabhāga avayavas. Each organ of the body is formed from specific bïjabhāgas or bijjabhāga avayavas. Such bijjabhāgas or bijabhāga avayavas are called as janakas (progenitors) of specific structures of the body and when defective can cause partial or total defects or absence of specific organs or parts of the body. Birth defects have been listed and described in the early Ayurvedic texts attributing defects of büjabhāgas and büjabhāga avayavas as the underlying cause. Blindness by birth and sexual anomalies are examples. Additionally, specific diseases have also been said to originate from defects in the components and component parts of the reproductive elements. Examples are skin diseases and haemorrhoids. The texts also differentiate between diseases originating from familial inheritance and other causes that affect the büjabhāgas. Congenital diseases are also listed and described separately. This paper is an attempt to critically review the descriptions related to medical genetics in the early classical texts of Ayurveda and to contextualise these speculations in the backdrop of the historical evolution of medical knowledge in the world.
\end{abstract}

Key words: Ayurveda, Medical Genetics.

\section{INTRODUCTION}

Medical genetics refers to the application of genetics in medical care. The diagnosis, management and counselling of patients with genetic disorders comes within the purview of medical genetics. The origin of medical genetics in modern times is traced to the period marking the culmination of the second world war around 1945.

Scholars are of the opinion that Aristotle could be considered to have discovered the principle implied in DNA, referring to the principle of the "unmoved mover" that "acts, creates form and development and is not unchanged in the process" (Vinci, Tom; Robert 2005). It was Aristotle who emphasized the importance of blood in heredity. He believed that the blood supplied the genetic material for development of all parts of the human body. Even today, we use the phrase "it is in the blood" to mean that certain traits are inherited from the parents. Speculations on heredity seems to have been recorded by the ancient Greeks as early as eighth to fourth century BC. Ancient Greek thinkers observed the inheritance of physical traits in humans. The concept of "Pangenesis" proposed by Hippocrates (460-377 BC) believes that people inherit acquired characteristics. He proposed that the entire organs of the parents contributed invisible seeds that were transmitted during conception to create the characters and features of the child (Manoli \& Fryssira, 2015).

\footnotetext{
* Research Director, Amrita Centre for Advanced Research in Ayurveda, Amrita Vishwavidyapeetham University, Kollam, Kerala, Email: rammanoharp@gmail.com
} 
The classical Ayurvedic texts dating several centuries before the Common Era have also proposed interesting observations and concepts about genetic disorders, which have not been adequately examined or acknowledged as contributions to the history of medical ideas. There are vivid accounts in ancient text books of Ayurveda like the Carka Samhitā about inheritance of diseases and the genetic basis for the transmission of such diseases from parents to the progeny. In this paper, we will examine some of these descriptions.

\section{DESCRIPTIONS OF GENETIC DISORDERS IN Classical Ayurvedic texts}

Classical Ayurvedic texts mention about genetic disorders with various terms like sahajarogas, kulajarogas or àdibalapravrttarogas. Diseases like haemorrhoids, certain skin diseases and diabetes are some of the diseases that have been considered to be inherited in Ayurveda. Sahajaroga means that which is present from birth (Agniveśa et al. 2013), Kulajaroga means that which runs in families(Agniveśa et al. 2013) and ádibalapravrttaroga (Dhanvantari et al. 2008) means that which arises from defects in the male and female reproductive elements. There are also many anomalies at birth which have been traced to have genetic origins in Ayurveda. The ancient physicians put forth theories to explain the phenomenon of genetically inherited diseases. Eight disorders by birth are also described in the Ayurvedic texts - giant and dwarf, obese and thin, hirsute and hairless, albinic and melanoid. Ayurvedic texts have also discussed various sexual anomalies at birth including impotency and maldevelopment of sexual organs.

\section{Theories Regarding THE GenetiC TRANSMISSION OF TRAITS}

We find some explanations in the Caraka Samhitā about specificity of the transmission of genetic information within a given species. From a human being, only a human being can be born. Just like molten metals poured into a mould takes the shape of a mould, even so various factors coalesce together to produce a human being from another human being. How does a human being bring forth another identical human being? In his commentary on the Caraka Samhitā, the famous commentator Cakrapānidatta points out that the human reproductive element (manusyabijam - lit. the seed from which the human being is born) is made up of many seed parts (bijjabhāga) representing the various organs and parts of the body (pratyanga). From this seed and its parts is born a replica human being with the same set of parts and organs. He further clarifies in another context that the bijabhāga or part of the seed has further subdivisions called bījabhāgāvayava. For example, if the part of the seed (bijjabhāga) represents the uterus, then the component of the part of the seed (bijabhāgāvayava) represents parts of the uterus. In this manner, from a human being, another life exhibiting the general features of human beings is born (Agniveœa et al. 2013). It is very tempting to compare the divisions of the human genetic material into the $b \bar{i} j a, b \bar{j} a b h \bar{a} g a$ and bijabhāgāvayava with the Chromosome, DNA and Gene described in modern genetics although there is no evidence to indicate that there was an understanding of the molecular basis of genetics as known to science today.

The schematic representation of the process of transmission of genetic diseases in Ayurveda is illustrated in Fig. 1.

By the term bijja both the male and female reproductive elements viz., Śukra - semen and Śnita - menstrual blood are taken. In certain contexts, the word $b \bar{i} j a$ means either one of them (Agniveśa et al. 2013) ${ }^{1}$.

\footnotetext{
${ }^{1}$ Cakrapāni defines these terms very clearly in his commentary. He says that büja means śukra and śonita - büjah śukraśonite. This means that both the male and female reproductive elements contribute to the genetic makeup of the individual. In another context, he defines bija as just śukra - bijje iti sukre.
} 


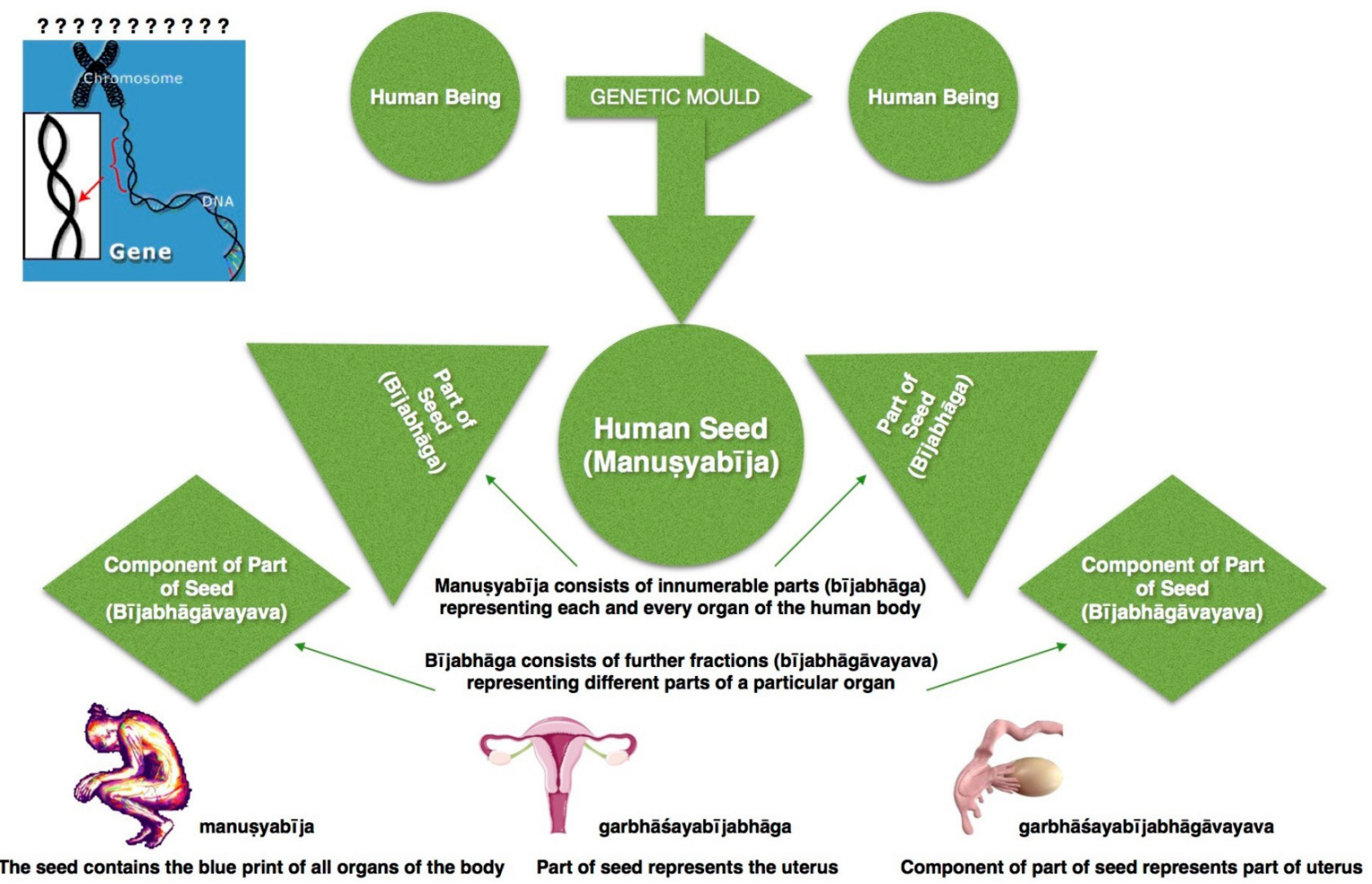

Fig. 1 Schematic Representation of the Genetic Transmission of Traits in Human Beings as described in classical texts of Ayurveda

The bijjabhāga is defined by Cakrapāni as those parts of the $b \bar{i} j a$ that are responsible for the development of specific parts and organs of the body $^{2}$ (Agniveśa et al. 2013).

The bijabhāgāvayava has been defined by Cakrapāni as components of the büjabhāga that are responsible for the development of specific parts of a particular organ, for example the uterus ${ }^{3}$ (Agniveśa et al. 2013).

\section{The transmission of Genetic Diseases as DESCRIBED IN THE AYURVEDIC TeXTS}

In Ayurveda, many diseases have been described to have genetic origins. In the description of diabetes, juvenile diabetes or diabetes at birth has been attributed to arise from genetic defects (bijadosa) ${ }^{4}$. In his commentary, Cakrapāni clarifies that diabetes at birth happens when the dosa that is responsible for the manifestation of diabetes damages the bīja or genetic material ${ }^{5}$ (Agniveśa et al. 2013). In the context of skin diseases the same theory is put forth to explain genetic transmission. The text explains that even if the father is affected by the disease, if the seed ( $b \vec{i} j a)$ has not been affected, then the progeny will not acquire the disease. On the other hand, if the seed ( $b \bar{i} j a)$ of the father has been affected by the disease, then the child will also inherit the disease. In Ayurveda, the rectum

\footnotetext{
${ }^{2}$ bījasyāngapratyanganirvartako bhāgo bījabhāgah

${ }^{3}$ garbhāśayabījabhāgāvayava ityatrāpi pūrvavadvyākhyeyam, avayavaśabdena garbhāśayasyārtavasya caikadeśa ihocyate

4 jātah pramehī madhumehino vā na sādhya uktah sa hi bījadoṣāt

${ }_{5}$ büjadoṣāditi, pramehārambhakadoṣaducmabījajātapramehitvāt
} 


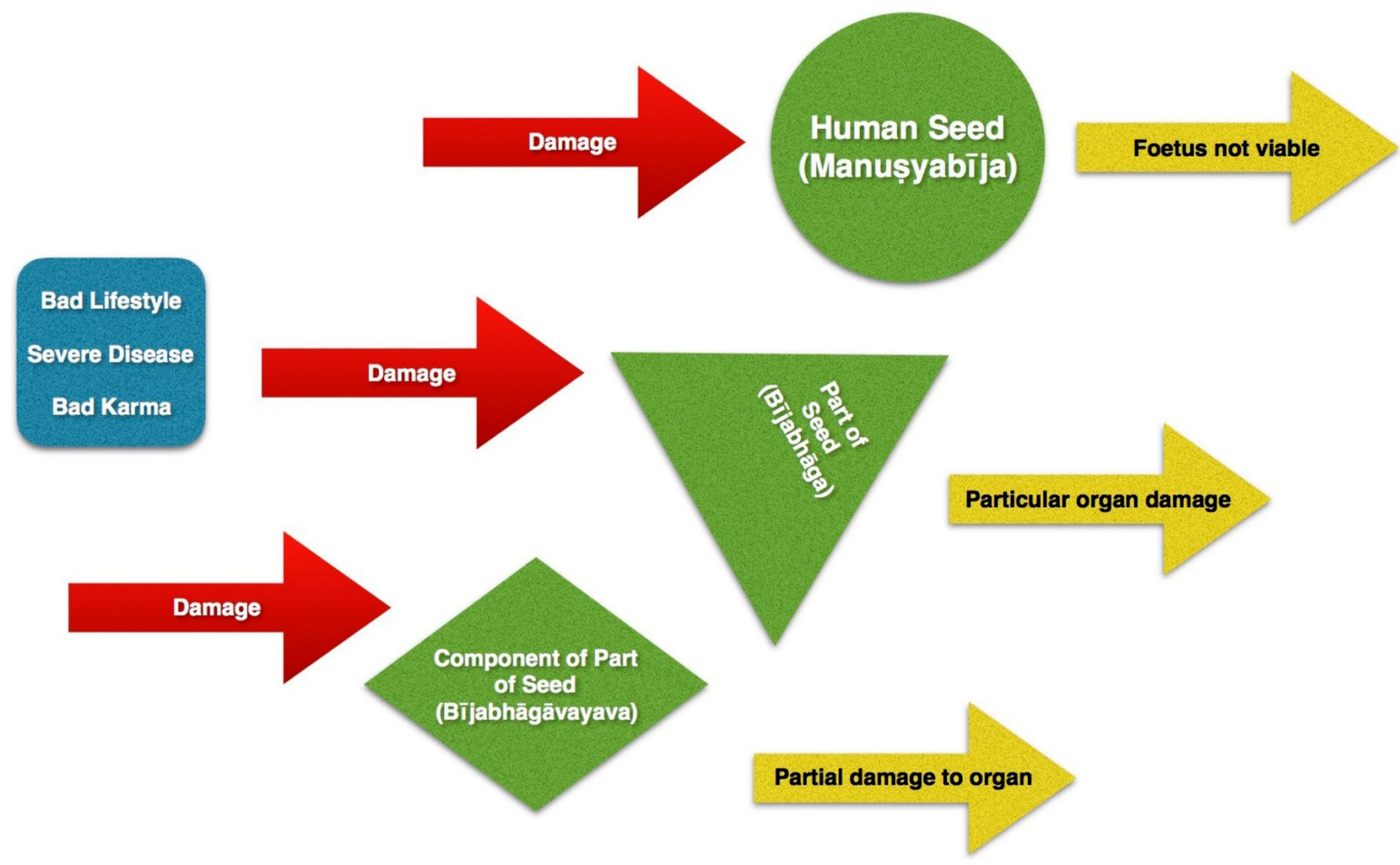

Fig. 2. Schematic Representation of causation of genetic diseases of Ayurveda

or guda is said to be made up of three rings called valīs. Haemorrhoids is considered to be also a genetically transmitted disease in Ayurveda. In other words, people can inherit susceptibility to the disease. Cakrapāni explains that this happens when the part of the seed (bijabhāga) that is responsible for the development of the gudavalīs or rings of the rectum, then the person develops haemorrhoids (Agniveśa et al. 2013).

Thus, the reason for genetic transmission of disease has been traced to the affliction (upatāpa) of the part of the seed (bijjabhāga) that is responsible for the development of the part of an organ ${ }^{6}$. Further it has been stated that defect caused by docas in the seed or part of the seed representing a particular organ will result in the complete damage to that particular organ ${ }^{7}$
(Agniveśa et al. 2013). The schematic representation of the genetic transmission of diseases is illustrated in Fig. 2.

In the Suśrutasamhitā, the genetics of conditions like blindness, dumbness and deafness at birth is explained. The question is raised as to how conception takes place and the child is born with defects in spite of the damage to the seed (bija). The answer is that the damage to the seed (bija) is partial and affects on a part of the seed (bijāvayava). When a part of the seed is affected, only the organs related to that part is afflicted ${ }^{8}$ (Dhanvantari et al. 2008).

When the part of the seed responsible for the development of the eyes is affected, a person is born blind ${ }^{9}$ (Dhanvantari et al. 2008).

\footnotetext{
${ }_{6}$ yasya yasya hyañgāvayavasya bīje bījabhāga upatapto bhavati tasya tasya hyañgāvayavasya vikrtirupajāyate

${ }^{7}$ yasya yasya hyavayavasya bīje bījabhāge vā doșāh prakopamāpadyante tam tamavayavam vikrtirāviśati

${ }^{8}$ tasmādya evāmśso büjasya dușto bhavati tatkāryasyaiva garbhāvayavasya vikrtirabhāvo vā bhavati

${ }^{9}$ yathā-drștyārambhake bījabhāge duște jātyandho garbho bhavati na tu garbha eva na bhavati
} 
In a similar way, the genetic basis for the formation of the docic constitution of an individual has also been explained by Dalhana in his commentary on Suśruta Samhitā. When the part of the seed that determines the expression of dosas get afflicted, the dominance of that particular dosa is seen in the individual and the other expressions are not affected ${ }^{10}$ (Dhanvantari et al. 2008).

A person with mixed sexual characteristics is born according to Caraka when the part of the seed responsible for the development of the male and female reproductive elements are equally afflicted $^{11}$ (Agniveśa et al. 2013).

When the part of the seed (bijjabhāga) representing the uterus is afflicted in the female reproductive element (śonita), then a barren woman is born. When the component of the part of the seed (bijjabhāgāvayava) representing the uterus is affected, then the woman gives birth to still borns. When the parts of the seed (bïjabhāga) responsible for the expression of feminine features are affected then a transgender woman is born who exhibits external characteristics of a woman devoid of the female genitalia (Agniveśa et al. 2013).

In a similar way, a sterile male is born when the part of the seed ( $b \bar{l} j a b h \bar{a} g a$ ) representing the male reproductive element is afflicted. When the component of the part of the seed (bijabhāgāvayava) representing the male reproductive element is afflicted a male whose progeny does not live is born. When the parts of the seed ( $b \bar{u} j a b h \bar{a} g a$ ) responsible for the expression of masculine characters are affected then a transgender man is born who exhibits external characteristics of a man devoid of male genitalia (Agniveśa et al. 2013).

\section{Discussion And Conclusion}

Genetic transmission of diseases was understood and described in the early stages of the evolutionary history of Ayurveda. The Caraka Saṃitā and the Suśruta Saṃitā, the earliest texts of Ayurveda, discuss about the genetic basis of diseases and also illustrate the concept citing examples of a few diseases.

Ayurveda also upholds the Indian tradition of marrying outside the gotra (Agniveœa et al. 2013). Gotra means a clan and refers to people who are descendants of a common male ancestor. People within the gotra are considered to be siblings. Scholars speculate that there may be a genetic basis for this practice, though the classical texts are silent on the medical or genetic reasons behind this tradition. There is an opinion that the gotra system prevents inbreeding and completely eliminates all recessive defective genes from the DNA.

Formal accounts of the history of genetics and especially medical genetics acknowledge the contributions of Greek thinkers like Aristotle and physicians like Hippocrates in ancient times. The contributions of Ayurveda to the history of medical ideas in the area of medical genetics is not well recognized.

The ancient physicians of Ayurveda put forth the theory that the entire genetic information representing each and every part of the human body was transmitted from the parents to the progeny. While the seed or bijja (the male and female reproductive elements) mapped the complete blue print of the human body, the part of the seed or bijabhāga represented specific body parts or organs. The part of the seed or bijabhägas were further made up of smaller components called the bijabhāgāvayavas which represented

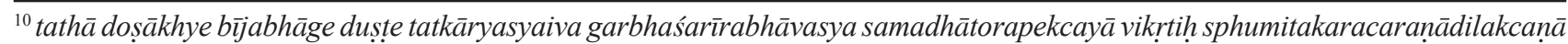
bhavati na tu garbhavyāghätah

${ }^{11}$ bìjāt samāṃśādupataptabìjāt strīpumsalingī bhavati
} 
parts of the organs. However, there is no evidence suggesting that they were able to decipher or isolate the actual physical structures that preserved and transmitted the genetic information.

The complete damage of the bija makes it impossible for the conception to happen or the fetus to be viable. Partial affliction of the part of the seed or its components cause partial defects to be present in the individual. Even the constitution of the person was considered to be determined by the parts of the seed and its components.

Ayurveda considered genetically inherited disorders to be incurable. The goal was to prevent genetic diseases by application of the methods of rejuvenation and reproductive medicine. Ayurveda also considered bad lifestyle and immoral life to be triggers for genetic diseases. For example, Cakrapanni explains that the reason for people being born blind is the damage to the part of the seed caused by the effect of past actions $(\text { karma })^{12}$ (Agniveśa et al. 2013).

The Ayurvedic understanding that physical constitution based on the preponderance of the docas has a genetic basis has recently found support from modern scientific research. P. Govindraj et al. discovered that PGM1 correlates with phenotype of Pitta as described in the ancient text of Caraka Samhita, suggesting that the phenotypic classification of India's traditional medicine has a genetic basis (Govindaraj et al. 2015).

\section{Biblography}

Agniveśa et al., 2013. Caraka Saṃhitā Y. Trikamji, ed., Varanasi: Chaukhambha Prakashan.

Dhanvantari, Susruta \& Nagarjuna, 2008. Suśruta Samhita Y. Trikamji \& N. Ram, eds., Varanasi: Chaukhamba Surabharati Prakashan.

Govindaraj, P. et al., 2015. Genome-wide analysis correlates Ayurveda Prakriti. Scientific Reports, 5, p.15786. Available at: http://dx.doi.org/10.1038/srep15786.

Manoli, I. \& Fryssira, H., 2015. Medical genetics and genomic medicine in Greece: achievements and challenges. Molecular Genetics \& Genomic Medicine, 3(5), pp.383-390. Available at: http://doi.wiley.com/ $10.1002 / \mathrm{mgg} 3.179$.

Vinci, Tom; Robert, J.S., 2005. Aristotle and Modern Genetics. Journal of the History of Ideas, 66(2), pp.201-221.

\footnotetext{
${ }^{12}$ andhatvādīndriyopaghātarūpe durdaivameva kāraṇạ̣
} 